\title{
RANCANG BANGUN SISTEM KONTROL PENIMBANGAN TEMBAKAU DENGAN MIKROKONTROLLER ARDUINO UNO
}

\author{
Bayu Irwanto \\ Fakultas Teknik, Program Studi Teknik Mesin \\ Universitas Muria Kudus \\ Email: irwantobayu5@gmail.com \\ Masruki Kabib \\ Fakultas Teknik, Program Studi Teknik Mesin \\ Universitas Muria Kudus \\ Email: masruki.kabib@umk.ac.id \\ Rochmad Winarso \\ Fakultas Teknik, Program Studi Teknik Mesin \\ Universitas Muria Kudus \\ Email: rochmad.winarso@umk.ac.id
}

\begin{abstract}
ABSTRAK
Pengukuran massa banyak dilakukan menggunakan timbangan konvensional, tetapi sistem ini memiliki kelemahan diantaranya adalah keakuratanya rendah dan kurang efisien waktu kerja. Hal ini dikarenakan harus memindahkan tembakau dari timbangan manual menuju alat press tembakau dengan tempat kerja yang terpisah. Penelitian ini bertujuan untuk merancang dan membuat sistem kontrol penimbangan tembakau menggunakan sensor load cell. Metodologi yang digunakan dalam perancangan dan pembuatan sistem penimbangan tembakau dengan sistem kendali Arduino Uno, pertama adalah. proses perancangan, gambar desain sistem kontrol, diagram blok sistem kontrol, pembuatan dan pengujian. Hasil penelitian adalah telah dibuat sistem penimbangan tembakau dengan keakurasian tinggi, presentase ketelitian dari timbangan adalah 99,8\%.
\end{abstract}

Kata kunci: timbangan tembakau, load cell, arduino Uno

\section{ABSTRACT}

Mass measurement is mostly done using conventional scales, but this system have weaknesses including low accuracy, and less efficient working time. This is because they must to move tobacco from manual scales to the tobacco press with a separate workplace. This research aims to design and build a weighing control system using a load cell sensor. The methodology used in the design and manufacture of tobacco weighing systems with Arduino Uno control systems, first is the design process, control system design drawings, control system block diagrams, manufacturing and testing. The results of research was maked a tobacco weighing system with high accuracy, the percentage of accuracy of the scales is $99.8 \%$.

Keywords: Tobacco Scale, load cell, arduino uno

\section{PENDAHULUAN}

Seiring berkembangnya ilmu pengetahuan dan teknologi mendorong manusia untuk menciptakan peralatan yang bermanfaat dan memudahkan pekerjaan manusia di berbagai bidang. Sistem kontrol mempunyai peranan yang penting dalam pengendalian proses produksi di industry [1].

Alat packaging pengepress tembakau kering menggunakan pneumatic telah membantu petani tembakau untuk proses pengepressan tembakau. Alat pengepress tembakau yang sudah ada masih kurang efektif. Dalam satu kali proses packaging tembakau kering masih membutuhkan dua tempat, di antaranya adalah yang pertama tempat mengepress tembakau kering, dan yang kedua tempat penimbangan untuk dilakukan proses penimbangan sampai mencapai massa $50 \mathrm{~kg}$. Timbangan adalah sebuah alat bantu yang digunakan untuk mengetahui berat suatu benda dalam hal ini adalah tembakau kering. Jenis timbangan yang biasa dipakai petani tembakau untuk penimbangan tembakau kering adalah timbangan manual.

Pengukuran massa yang biasanya menggunakan timbangan manual memiliki kelemahan di antaranya adalah keakuratanya rendah dan kurang efisien waktu kerja, untuk menyikapi hal tersebut sekarang telah banyak dikembangkan menjadi timbangan elektronik berbasis Load Cell. Pengguna timbangan elektronik hanya melihat angka yang tertera pada layar LCD (Licuid Crystal Display [2].

Load cell merupakan sensor yang cukup popular untuk pengukuran massa (timbangan elektronik), penggunaan load cell sangat simple dan sangat memudahkan dalam implementasinya. Prinsip kerja secara singkat dari load cell adalah terjadinya shears atau stress dari suatu benda (misalnya logam). Load cell mempunyai mekanisme dimana shears dan stress ini diwujudkan dalam bentuk perubahan panjang (regangan) 
permukaan dan perubahan panjang ini ditangkap oleh sensor sekunder berupa strain gauge yang akan mengubah perubahan panjang (regangan) menjadia perubahan resistansi. Selanjutnya akan diprogram di Arduino Uno sebagai pengendali [3].

Load Cell yang banyak dipakai adalah tipe Single point. Kelebihan dari load cell single point adalah kapasitas beban yang ditimbang adalah 20,50,100, 150, $200 \mathrm{~kg}$ dan dapat menimbang beban yang kecil [4]. Load cell diberi beban pada inti besi maka nilai resistansinya di strain gauge nya akan berubah yang dikeluarkan melalui empat buah kabel. Dua kabel sebagai eksitasi dan dua kabel lainya sebagai sinyal keluaran kontrolnya [5].

Tegangan keluaran dari Load Cell sangat kecil, sehingga untuk mengetahui perubahan tegangan keluaran secara linier dibutuhkan rangkaian penguat instrument yang dapat menguatkan tegangan keluaran yang sangat kecil hingga kurang dari satuan mili volt [6]. Modul HX711 adalah modul timbangan yang memiliki prinsip kerja mengkonversi perubahan yang terukur dalam perubahan resistensi dan mengkonversi keadalam besaran tegangan [7].

Penelitian ini bertujuan untuk merancang dan membuat sistem control penimbangan tembakau menggunakan sensor Load Cell dan mikrokontroller Arduino uno.

\section{METODOLOGI PENELITIAN}

Perancangan dan pembuatam sistem kontrol timbangan elektronik dengan sistem kendali Arduino Uno memerlukan beberapa langkah yang dapat dilihat pada gambar 1 dibawah ini.

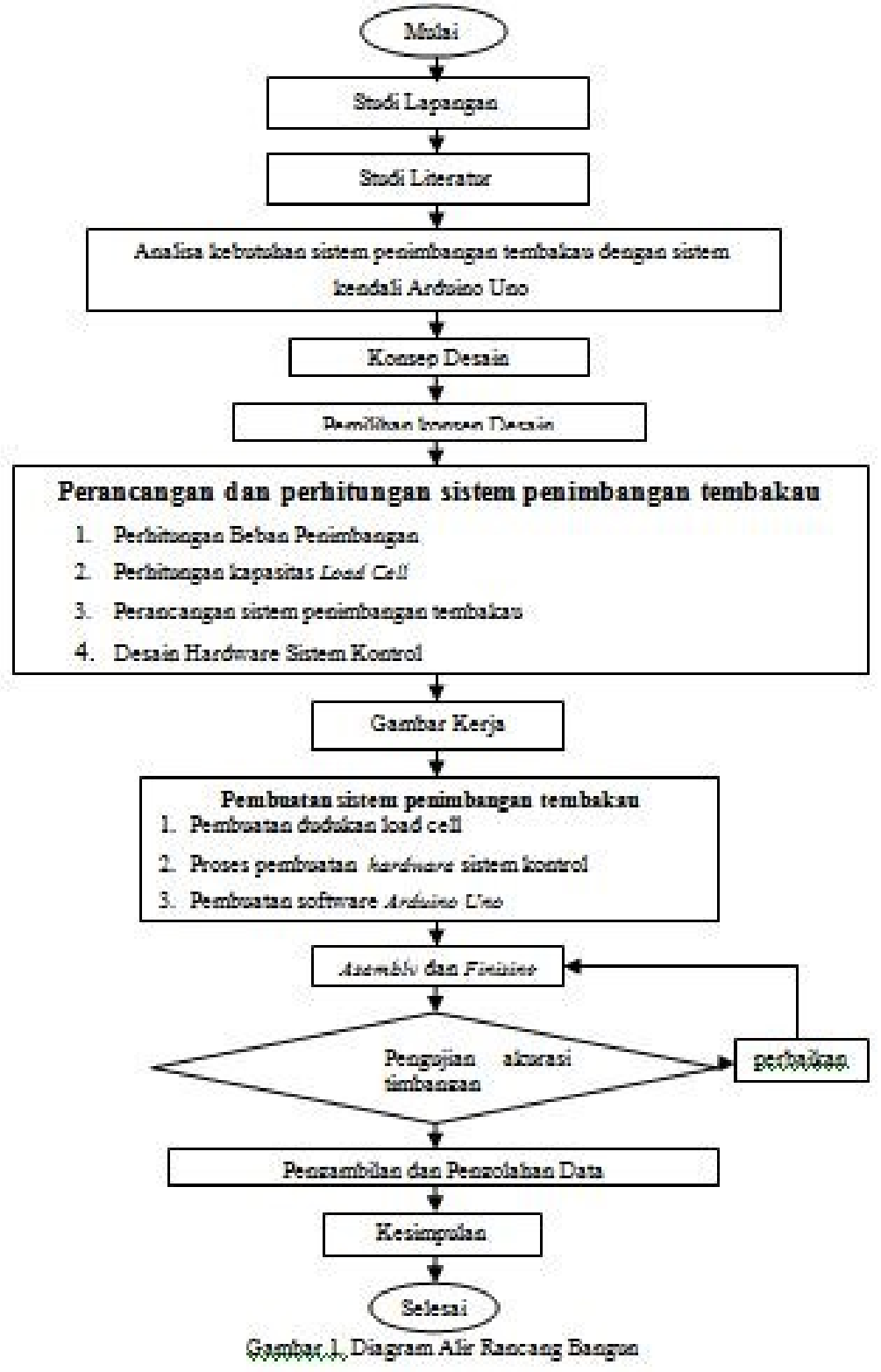


Studi literature untuk mencari sumber-sumber terkait dan pembanding awal dalam proses rancang bangun sistem penimbangan tembakau dalam suatu penelitian. Konsep desain dapat dapat dilihat dari analisa kebutuhan, meliputi aspek teknik, aspek manufaktur, aspek produksi, aspek ergonomis, aspek keselamatan kerja. Perancangan dan perhitungan sistem penimbangan tembakau meliputi perhitungan Beban Penimbangan, Perhitungan kapasitas Load Cell, Perancangan sistem penimbangan tembakau, Desain hardware Sistem Kontrol. Pembuatan sistem penimbangan tembakau meliputi pembuatan dudukan load cell, Proses pembuatan hardware sistem kontrol, Pembuatan software Arduino Uno. Pengujian keakurasian timbangan tembakau, selanjutnya pengambilan dan pengolahan data.

\section{HASIL DAN PEMBAHASAN}

\subsection{Konsep Desain}

Pada gambar 2 menunjukan desain mesin penimbang tembakau dengan arduino uno. Mesin ini dilengkapi dengan Load Cell, LCD, dan Modul HX711.
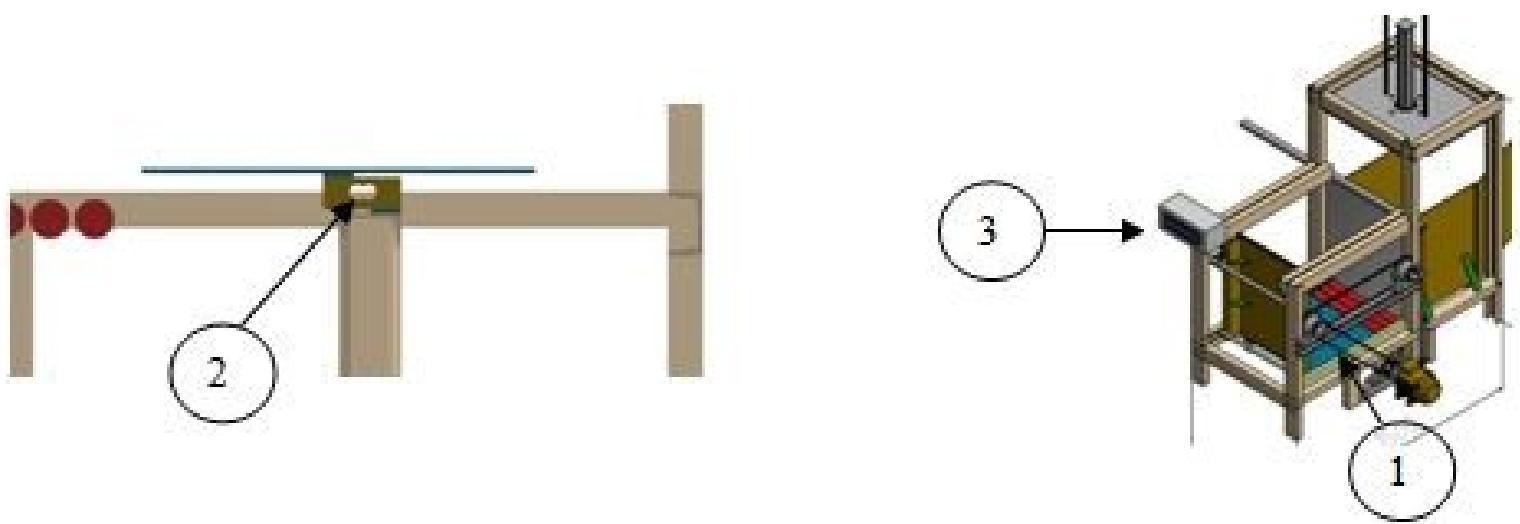

Gambar 2. Desain mesin penimbangan tembakau

Mesin ini dilengkapi dengan komponen - komponen sebagai berikut pertama (1) plat penimbang, kedua (2) Load Cell, ketiga (3) Lcd dan Modul HX711.

Gambar 3 merupakan diagram blok sistem kontrol penimbangan tembakau dengan menggunakan mikrokontroller arduino uno.

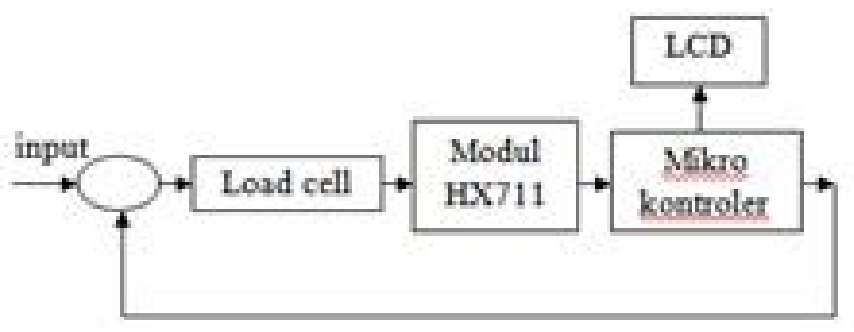

Gambar 3. Diagram sistem kontrol penimbangan tembakau

Diagram pada gambar 3 merupakan sistem kontrol penimbangan melalui yang pertama input merupakan berat tembakau kemudian dibaca oleh sensor Load Cell kemudian di konversi tegangan menjadi sinyal melalui modul HX711, kemudian di baca oleh mikrokontroler, kemudian ditampilkan pada LCD.

\subsection{Pembuatan hardware}

Pada gambar 4 dibawah ini menunjukan hardware sistem penimbangan tembakau dengan menggunakan mikrokontroller arduino uno. Cara kerja sistem penimbangan tembakau sebagai berikut, tembakau ditaruh diatas plat penimbangan, kemudian massa tembakau memberi sinyal ke load cell dan penguat sinyal modul HX711 untuk membaca tegangan dari Load Cell (sensor massa), menmpilkan Lcd untuk membaca massa hasil penimbangan tembakau, keluaran dari lcd berupa angka yang menunjukkan besaran massa. 


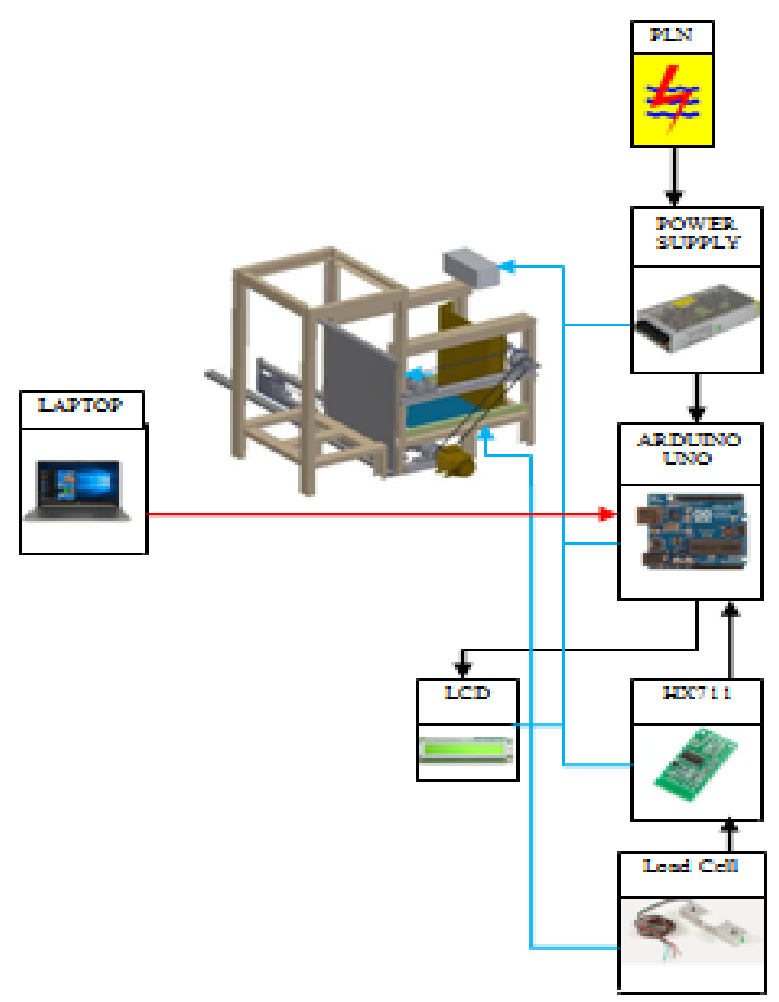

Gambar 4. Pembuatan Hardware

\subsection{Perhitungan Beban Penimbangan}

Perhitungan beban bertujuan untuk menghitung kapasitas load cell yang diperlukan, berikut langkah - langkah untuk menentukan beban penimbangan seperti pada gambar 5 .

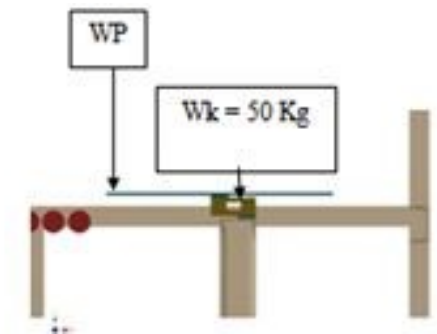

Gambar 5. Perhitungan Beban Penimbangan

Perhitungan massa total menggunakan persamaan 1.

Wtotal $=\mathrm{Wk}+\mathrm{Wp}$

Dimana : $\quad \mathrm{Wk} \quad=$ Massa Tembakau

$\mathrm{Wp}=$ Massa Plat

Wtotal $=$ Massa Total

Tabel 1. Perhitungan beban penimbangan

\begin{tabular}{ccc}
\hline $\mathrm{Wk}(\mathrm{kg})$ & $\mathrm{Wp}(\mathrm{kg})$ & Wtotal $(\mathrm{kg})$ \\
\hline 50 & 14,9 & 64,9 \\
\hline
\end{tabular}

Tabel 1 Menunjukan perhitungan beban penimbangan, dari perhitungan dihasilkan massa tembakau (Wk) $=50 \mathrm{~kg}$, massa Plat $(\mathrm{Wp})=14,9 \mathrm{Kg}$, Massa total $=\mathrm{Wk}+\mathrm{Wp}=64,9 \mathrm{Kg}$. 


\subsection{Perhitungan Kapasitas Load Cell}

Perhitungan kapasitas Load Cell bertujuan untuk menghitung keperluan, berikut langkah - langkah untuk menentukan beban penimbangan dapat dilihat pada tabel 2, dengan menggunakan persamaan 2 sebagai berikut.

$\mathrm{Kl}=$ Wtotal $\mathrm{x}$ factor keamanan

Tabel 2. Perhitungan Kapasitas Load Cell

\begin{tabular}{ccc}
\hline Wtotal $(\mathrm{kg})$ & Faktor Keamanan & $\begin{array}{c}\mathrm{Kl}=\text { Wtotal x Faktor keamanan } \\
(\mathrm{kg})\end{array}$ \\
\hline 64,9 & 2 & 138 \\
\hline
\end{tabular}

Tabel 2 menunjukan hasil perhitungan Wtotal $(\mathrm{Kg})$ dikalikan dengan faktor keamanan sehingga mendapatkan kapasitas Load Cell $(\mathrm{Kl})=138 \mathrm{~kg}$.

\subsection{Proses Pengujian}

Pengujian kerja timbangan tembakau dengan pengambilan data pembandingkan berat tembakau dengan timbangan manual ( konvensional) dan timbangan otomatis yang dibuat, berikut merupakan pengujian timbangan tembakau yang dilakukan.

Tabel 3. Hasil Pengujian Timbangan

\begin{tabular}{cccc}
\hline No & $\begin{array}{c}\text { Timbangan } \\
\text { Konvesional }(\mathrm{kg})\end{array}$ & $\begin{array}{c}\text { Timbangan yang } \\
\text { dibuat }(\mathrm{kg})\end{array}$ & $\begin{array}{c}\text { Penyimpangan } \\
(\mathrm{Wtm})\end{array}$ \\
\hline 1 & 1 & $(\mathrm{Wtl})$ & $(\mathrm{Wtm}-\mathrm{Wtl})$ \\
2 & 10 & 1 & 0 \\
3 & 15 & 9,95 & 0,05 \\
Rata - Rata $(\Sigma)$ & 8,66 & 14,98 & 0,02 \\
\hline
\end{tabular}

Ketelitian penimbangan dihitung berdasarkan persamaan 3 dan 4.

$\%$ kesalahan $\quad=\left|\frac{\sum W t m-\sum W t l}{\sum W t m}\right| \times 100 \%$

$\%$ ketelitian $=100 \%-\%$ kesalahan

Hasil pengujian timbangan yang telah dibuat, presentase ketelitian dari timbangan adalah 99,8\%. Hasil ini menunjukkan bahwa penimbangan dengan sensor load cell memiliki keakauratan yang baik.

\section{KESIMPULAN}

Hasil penelitian ini adalah telah di rancang dan dibuat sistem kontrol penimbangan tembakau yang dibuat menggunakan sensor massa (Load Cell) dengan sistem kendali menggunakan mikrokontroller Arduino Uno. Sistem penimbangan tembakau ditaruh diatas plat penimbangan, kemudian massa tembakau memberi sinyal ke load cell dan Memerintahkan modul HX711 untuk membaca tegangan dari Load Cell (sensor massa), Memerintahkan Lcd untuk membaca berat hasil penimbangan tembakau, keluaran dari Lcd berupa angka Hasil pengujian timbangan yang telah dibuat di dapatkan presentase ketelitian dari timbangan adalah 99,8\%.

\section{DAFTAR PUSTAKA}

[1] P. Kushartanto, M. Kabib, R. Winarso, 2019, "Sistem Kontrol Gerak Dan Perhitungan Produk Pada Mesin Pres Dan Pemotong Kantong Plastik," Jurnal Crankshaft, Vol. 2, No. 1, Pp. 57-66.

[2] P. M. N. Manege, E. K. Allo, 2017, "Rancang Bangun Timbangan Digital Dengan Kapasitas 20 Kg Berbasis Microcontroller,” Jurnal Teknik Elektro Dan Komputer, Vol. 6, No. 1, Pp. 57-62.

[3] D. Agung Nugraha, 2017 “Timbangan Gantung Digital Dengan Sensor Hx711 (Load Cell) Berbasis Arduino Uno," Proyek Akhir, Departemen Fisika, Fakultas Mipa, Universitas Sumatera Utara. 
[4] P. Gunawan, 2016, “Rancang Bangun Sistem Timbangan Otomatis Berbasis Atmega328,” Proyek Akhir, Departemen Fisika, Fakultas Mipa, Universitas Sumatera Utara.

[5] Ainul, 2016,"Rancang Bangun Timbangan Beras Digital Dengan Keluaran Berat Dan Harga Berbasis Mikrokontroler," Skripsi, Jurusan Teknik Informatika, Fakultas Sains Dan Teknologi, Uin Alauddin Makassar

[6] E. F. Yandra, B. P. Lapanporo, And M. I. Jumarang, "Rancang Bangun Timbangan Digital Berbasis Sensor Beban 5 Kg Menggunakan Mikrokontroler Atmega328,” Positron, Vol. 6, No. 1, Pp. 23-28, 2016.

[7] P. C. Setianingrum, P. Studi, T. Elektro, F. Sains, D. A. N. Teknologi, And U. S. Dharma, 2017

"Timbangan Buah Digital Berbasiskan Digital Fruit Scales Based On," Tugas Akhir, Program studi teknik Elektro Fakultas Sains Dan teknologi Universitas Sanatadharma Yogyakarta 